\title{
A Recently Discovered Regimen sanitatis by Guillem de Béziers from 1319
}

\author{
Dana Stehlíková \\ (Masaryk University, Brno)
}

\begin{abstract}
The Montpellier physician Guillem de Béziers († 1322) was known as the author of two practice-oriented medical texts - the Informatio scolaribus suis and the Documentum. The article presents a newly discovered manuscript with another Guillem's treatises, the Regimen sanitatis, which is preserved in the Museum and Gallery of the Eagle Mountains in Rychnov nad Kněžnou (Muzeum a galerie Orlických hor v Rychnově nad Kněžnou) in the Czech Republic. The introductory part, in which Guillem's possible sources are discussed in detail, is followed by a critical edition of the Latin regimen.
\end{abstract}

\section{Keywords}

medieval medical literature; regimina sanitatis; Guillem de Béziers; medieval university of Montpellier

This paper is published as part of the interdisciplinary research project of Masaryk University 'Herbaria manuscripta Bohemiae et Moraviae usque ad annum 1500 - databáze rukopisných herbářů do roku 1500 jako platforma ke studiu humanitních i prrírodovědných disciplín' (The Herbaria manuscripta Bohemiae et Moraviae usque ad annum 1500 - database of manuscripts of herbals up until the year 1500 as a platform to study humanities and natural sciences; MUNI/G/1059/2018).

Special thanks to Prof. Michael McVaugh for a thorough reading of the edition and for his kind and valuable suggestions and comments. 
The literary work of physicians teaching in Montpellier at the beginning of the 14th century has long been of interest to literary historians. ${ }^{1}$ In addition to famous teachers such as Arnald of Villa Nova († 1311) and Bernard of Gordon ( $†$ after 1308), we know the names of other contemporaries who worked at the Faculty of Medicine in Montpellier and who were able to break free of dependence on authoritative texts and create original medical treatises. One of the lesser-known physicians was Guillem de Béziers (Guillelmus de Biterris), the author of the Informatio scolaribus suis, which was written in $1320 .^{2}$ The text survives in four manuscripts and was critically published in $2003 .^{3}$ As the title suggests, the text is undoubtedly related to Guillem's teaching practice. It is introduced by a short prologue, followed by a description of what the room of a patient with a fever should look like. The main part of the Informatio consists of about 60 recipes arranged according to the forms of compound medicines for syrups, enemas, pessaries, and suppositories. At the beginning of each section, the author lists the types of syrups, enemas, and suppositories, and then presents various recipes. At the very end, there are two recipes for syrups ad appetitum malum for convalescents caused by an imbalance (discrasia), which persists in the body after a disease. It is thus not just a list of recipes that we know from antidotaries, but an independent medical work, the author of which pursues didactic goals and strives for logical continuity in the text. At the same time, the editors of the Informatio published another small recipe collection by the same author, which is referred to in the only known manuscript as Documentum magistri G. de Biterris. ${ }^{4}$ Unlike the Informatio, this is a more concise list of less than two dozen recipes, especially for the treatment of fever, in which the author's style is somewhat noticeable only in a short paragraph devoted again to the conditions of the room of a fever patient. Due to certain content similarities, both published recipe collections are likely to be the works of the same author.

The article within which both texts were published also presents the most detailed biography of Guillem de Béziers, which is based on the study of new archival documents from the Archivo de la Corona de Aragón, made available in their full original versions. ${ }^{5}$ At this point, we will therefore confine ourselves to recalling the generally known facts of Guillem's life. Guillem studied medicine in Montpellier and 1301 became the first teacher of medicine at Lleida, where he had been summoned by King James II of Aragon. ${ }^{6}$ However, his teaching career there was neither too intense (Guillem was at that time also a physician to the royal family) nor too long (the school in Lleida was closed

1 For more information on the medical school in Montpellier, see Dulieu, L. (1975); Le Blévec, D. (Ed., 2004); Dumas, G. (2015).

2 Wickersheimer, E. (1936: p. 244), Wickersheimer, E. \& Jacquart, D. (1979: p. 106), Thorndike, L. \& Kibre, P. (1963: col. 1232).

3 McVaugh, M. \& Martínez Gázquez, J. \& †García Ballester, L. (2003: pp. 18-28); Sudhoff, K. (1918: p. 408) was the first to draw attention to this text.

4 McVaugh, M. \& Martínez Gázquez, J. \& †García Ballester, L. (2003: pp. 28-29).

5 McVaugh, M. \& Martínez Gázquez, J. \& †García Ballester, L. (2003: pp. 9-18).

6 McVaugh, M. \& García Ballester, L. (1989: pp. 1-25). For Guillem's teaching in Lleida, see also McVaugh, M. R. (1993: pp. 9 and 83-84). 
temporarily soon after 1304). Guillem then apparently returned to Montpellier to teach medicine (focusing on practical medicine), ${ }^{7}$ but until 1306 he also worked as a physician to King James II. ${ }^{8}$ His medical services were later used by Pope John XXII (Pope during 1316-1334), based in Avignon. Guillem held the title of Chancellor of the University of Montpellier in 1320 and died at the end of 1322. Although many diplomatic sources documenting Guillem's life in the early 14th century have been preserved, after 1306 his name completely disappeared from the sources for about 15 years. As we will show below, however, it is now possible to narrow this time gap at least a little thanks to a newly found source from 1319.

Now we could use a fairy-tale topos - once upon a time in a land far, far away, there lay a manuscript lost and forgotten - and we would not be far from the truth. Twelve unbound paper sheets from the first half of the 14th century, which contain several medical texts by different authors, including Guillem de Béziers, have been preserved in the Museum and Gallery of the Eagle Mountains in Rychnov nad Kněžnou (Muzeum a galerie Orlických hor v Rychnově nad Kněžnou) in the Czech Republic, in a town more than 1,500 kilometres from Montpellier. The only thing known about the fate of these sheets is that they were originally owned by the Municipal Museum in nearby Kostelec nad Orlicí (Městské muzeum v Kostelci nad Orlicí), which existed from 1893 until 1964. The inventory number of the papers in that museum was 440-C 5. After the abolition of the museum, its collections were transported to Rychnov nad Kněžnou. The papers escaped the attention of researchers because there is no collection of medieval manuscripts in the museum in Rychnov - these sheets are the only medieval manuscript owned by the museum, and, therefore, they do not even have an inventory number.

The content of the manuscript was published in 1992 by Josef Tříška, who was at that time preparing an inventory of medieval manuscripts in the chateau library of the Counts of Kolowrat in Rychnov nad Kněžnou and on that occasion also studied the museum's only manuscript. ${ }^{9}$ However, Třśška did not manage to correctly identify all of the texts, and there are some other mistakes in his description. Moreover, he did not notice that the sheets had been placed in the wrong order and provided with incorrect pagination in the past (probably by a city librarian in Kostelec). Therefore, we will present the complete contents of the entire fragment here:

p. 1a Quid pro quo, fragmentum; inc. pro pipere albo nigrum duplex..., expl. ...pro zinzibere piretrum)

pp. 1b-3b Bernardi de Gordonio De decem ingeniis curandorum morborum; inc. Ingenia curacionis morborum..., expl. ...cum integritate sicut scitis. Explicit tabula ingeniorum curandi morbos secundum Bernardum de Gordonio. ${ }^{10}$

7 Dumas, G. (2015: pp. 180, 183).

8 Regarding his services to the royal family, see McVaugh, M. R. (1993: pp. 10-12).

9 Tř́šska, J. (1992: pp. 143-144). The manuscript is also briefly mentioned by Tošnerová, M. (2001: p. 160).

10 In the final paragraph, the file dates to 1290 (... Facta auto fuit hec ordinacio in preclaro studio Montis Pessulani anno domini $M^{\circ} C C^{o} L X X X X$ mense Iulii die Mercurii post festum beati Marcialis...), while in other manuscripts it 
p. $4 a-b$

p. $4 \mathrm{~b}$

p. $5 a-b$

p. $5 b$

p. $6 a-b$

pp. $7 \mathbf{a}-10 a$

p. $10 a-b$

pp. 11a-16a

pp. $16 a-17 b$

p. 17b

pp. 18a-21a

pp. 21a-23b

p. $24 a-b$
Alfani Salernitani De quatuor humoribus; inc. Alfani archiepiscopi liber incipit de 4 humoribus extra cursum suum exeuntibus. Quoniam humanum corpus ex $4^{\text {or }}$ humoribus constat..., expl. ... plante pedum fortiter radantur et cum aqua salsa laventur. ${ }^{11}$ Recepta varia medica; inc. Magister Gilbertus: utatur syrupo subscripto cum aqua... (in margine contra ptisim), expl. ...et fiat ungentum. ${ }^{12}$

Passiones puerorum; inc. Passiones puerorum adhuc in cunabulis existencium..., expl. ...pulvis origani, pulegii, calamenti et hec sufficiant ex predictis. ${ }^{13}$

Trotulae De sinthomatibus, fragmentum; inc. Quoniam febris plus ledit proprio sinthomate..., expl. ...non debet fluxus ex toto intercipi sed muniatur.

Rogerii de Barone De aquis physicalibus (Rogerina minor), excerpta; inc. Quoniam non minus indiget natura aquis physicalibus..., expl. ...sub aqua non extinguetur.

Quaestiones variae medicae; inc. Utrum mulier pregnans a $10^{\circ}$ mense usque ad $9^{m}$ sit purganda, expl. ...cicius apparent lentigines in facie quam in membris aliis. ${ }^{14}$

Propositiones philosophicae necnon medicae; inc. Cause secunde illuminantur a lumine cause prime..., expl. ...ideo primo regracior deo glorioso a quo homo esse et vivere etc.

Arnaldi de Villa Nova Tabulae super Vita brevis (initium in pp. 13-14, continuatio in pp. 11-12, finis in pp. 15-16); inc. Cum Ypocras more sapientis..., expl. ...quod fuerit male qualitatis. Explicit tabula magistri Arnoldi de Nova Villa. ${ }^{15}$

Gualteri Agulini Contenta de urina, inc. Notandum quod in determinacione urine talia sunt inquirenda...; expl. ...signat dolorem ypocondriorum dextri et sinistri. Expliciunt contenta Galteri. Deo gracias.

Recepta varia medica; inc. Ad duriciem splenis..., expl. ...et fiant ungentum.

Iohannis Damasceni Aphorismi; inc. Certe in medicina inmensa est profunditas..., expl. ... id ante oculos pone, contrarium vero contrario. Expliciunt amphorismi Iohannis Damasceni. ${ }^{16}$

Guillelmi de Biterris Regimen sanitatis; inc. Incipit regimen sanitatis editum a magistro Willhelmo de Biterris anno domini $M^{\circ}$ CCCI XIX ${ }^{\circ}$. Averoys in primo Collectorii sui dicit..., expl. ... ut pervenire possumus ad gaudia sapientis. Amen. Explicit. Guillelmi de Biterris Informatio scolaribus suis, fragmentum; inc. Clistere mollificativum sic fit...; expl. ...sumantur in panno lineo subtili et extra.

dates to 1299, cf. Sudhoff, K. (1917: p. 166), Demaitre, L. E. (1980: pp. 47, 157; Thorndike, L. \& Kibre, P. (1963: col. 744).

11 Thorndike, L. \& Kibre, P. (1963: col. 1277).

12 A total of seven recipes for various diseases, only the first two explicitly by Gilbertus Anglicus.

13 Thorndike, L. \& Kibre, P. (1963: col. 1028).

14 A total of 26 questions regarding pregnant women, childbirth, breast milk, deafness in children, rheumatism, nose bleeding, cleft palates, teeth, halitosis, and freckles.

15 Thorndike, L. \& Kibre, P. (1963: col. 301).

16 The otherwise common incipit Ecce autem amphorismos quos me rogasti tue dileccioni transmitto is titled with a different hand. Regarding both incipits, see Jacquart, D. \& Troupeau, G. (Eds., 1980: p. 23); Thorndike, L. \& Kibre, P. (1963: col. 201). 
As can be seen, both texts from authors associated with the medical faculty at Montpellier and writings of the Salerno school appear together in the manuscript. These are mostly texts preserved in other medieval manuscripts, apart from Guillem's regimen (pp. 21a-23b). Since it is not known from elsewhere that Guillem would be the author of any regimen sanitatis, the attribution of the Rychnov manuscript may seem very suspicious at first glance. However, there are several reasons the attribution should be regarded as reliable. Each one of them would probably not be valid enough on its own, but all of them together are convincing.

1. The regimen has been preserved in an old copy, which was written in the first half of the 14th century, i.e. at a time close to Guillem's life.

2. The manuscript mentions the year 1319 as the date of the regimen's being completed, which fits quite well into Guillem's biography. Guillem held the title of Chancellor of the University in 1320, and although we do not have any direct evidence of his previous teaching career in Montpellier, he likely got involved in teaching medicine before 1320, which is why he became Chancellor. It is possible that he was already there from 1305 after the school in Lleida was temporarily closed. ${ }^{17}$

3. A fragment of Guillem's Informacio is written in the manuscript, immediately after the regimen, to the extent of one page. It covers about $40 \%$ of the entire text of the Informatio. The beginning, as we know it from other manuscripts, must have been deliberately omitted when copying, because the Rychnov incipit is written at the top of the verso page. The end, on the other hand, has been lost over the centuries the 12th sheet, on which the end of the regimen and the Informacio fragment are written, is the last preserved sheet of the entire set, and the text ends in the middle of a sentence.

4. The preserved regimen sanitatis corresponds to the way in which the Informacio scolaribus suis is written (see below).

5. There is matching content among the Informacio, the Paris Documentum, and the regimen in recommending how to cool a room:

Informacio, p. 19 in the edition

...debet artificialiter cameram infrigidare cum foliis vitium et salicis et rosis... Et debet tenere in camera ollas sive urnas plenas aqua dulci frigida...
Documentum, p. 28 in the edition

...post riga ipsam domum cum aqua dulci actualis frigiditatis. Iterum fac colligere foliam vitium albarum et salicum et talium aerem refrigerantium...
Regimen sanitatis, p. $21 \mathrm{~b}$

... expedit ... ut corpori applicetur aer declinans ad frigiditatem, et si non sit tale, preparetur artificialiter, ut in domo ponantur flores vel herbe frigide ... flores nenufaris vel viole recentis vel rose rubre suis temporibus vel salices vel folia vicium vel consimilia. Locus irroretur aquis dulcibus, ut per hoc aer acquirat frigiditatem...

17 McVaugh, M. R. (1993: p. 12). 
Guillem's regimen could have become known three decades ago. However, Josef Tř́šsa did not have enough time to get acquainted with the scribe's handwriting and his method of abbreviating, and so he read the author's name in the incipit incorrectly as a magistro Willero de Vicerris (instead of Willhelmo de Biterris). ${ }^{18}$ It is therefore not surprising that Třiśska failed to connect the text with a well-known figure in the field of medical literature. Furthermore, Třŕška considered the last page, which contains Guillem's Informacio, to be the end of the regimen. Even if he would have noticed the boundary between the text of the regimen and the Informacio, the latter was a fragment without the incipit, according to which it would have been possible to come to the name of Guillem de Béziers, probably almost unknown in medieval Bohemia. But not completely unknown. In the manuscript I F 35 of the National Library of the Czech Republic in Prague, f. 257v-259r, we can read a brief antidotarium with the incipit Inicipit Tabula sive Flores antidotarii pro faciliori invencione opiatarum et recepta contra morbos and the colophon Et sic est finis nostri Anthidotarii Fr. M. Ber. pronuncciati per M. G. de Bitteriis suis studentibus publice in scolis ad practicam medicine. ${ }^{19}$ The text is a part of the collection Confundarium maius, completed in 1431 by Matthaeus Beran, an Augustinian canon from Roudnice nad Labem, during his exile in Erfurt. ${ }^{20}$ This text does not correspond to either the Informacio or the Documentum and is not previously known from any other manuscript. It represents an elementary overview of complex drugs for various diseases. It does not have a graphic design in the form of a tabula, such as those we can see in the well-known Tabulae of Arnald of Villa Nova (e.g. in the Rychnov manuscript) or the Tabula antidotaria by the well-known Montpellier physician and translator Armengaudus Blasius ( $\uparrow 1312),{ }^{21}$ whom Guillem must have known in person as they both lived in Montpellier and were in the service of the King of Aragon. ${ }^{22}$

Nevertheless, let us return to the more literarily interesting regimen sanitatis. It is a text belonging to an immensely popular genre of medical literature, ${ }^{23}$ cultivated even in an academic milieu, as each physician should have been able to set a tailor-made regimen for their patient and therefore had to be acquainted with the general principles of dietetics. Guillem likely wrote the regimen for his students as a sample of a general regimen sanitatis for healthy adults, which describes how a conservator sanitatis ${ }^{24}$ should look after their health. Following the prologue, the content of the regimen is divided into the com-

18 Cf. Tříška, J. (1992: p. 144).

19 Truhlář, J. (1905: p. 110).

20 Doležalová, L. (2015: pp. 126-140, relevant mainly pp. 130-131 and p. 138). The manuscript is available at http://www.manuscriptorium.com.

21 Ed. by McVaugh, M. \& Ferre, Lola (2000).

22 McVaugh, M. R. (1993: p. 12).

23 Regarding this genre, see Schmitt, W. (1979: pp. 18-35), Gil Sotres, P. (1993: pp. 399-438), Weiss Adamson, M. (1995), Nicoud, M. (2007), Schmitt, W. (2013).

24 The influence of Avicenna's († 1037) compendium Canon medicinae, which was translated by Gerhard of Cremona in the second half of the 12th century, is evident here. Avicenna focuses mainly on dietetics in book 1, fen 3 (where the term conservator sanitatis appears), but some other regimen themes are also scattered in books 3 and 4, see especially Schmitt, W. (2013: pp. 124-129). For the needs of this work, the incunabula Liber canonis ... quem princeps Aboali Abincenni de medicina edidit was consulted (Venetiis 1483). 
mon categories of medieval regimina, i.e. six chapters according to res non naturales (i.e. the basic areas affecting human health), without Guillem using the term itself. ${ }^{25}$ The author presents remarkably simple, easy-to-remember instructions that are generally valid for any healthy human being and shows by way of example how these pieces of advice should be applied when the human body is in a state of humour imbalance (corpus distemperatum). He completely refrains from theoretical explanations.

Guillem's regimen belongs to the golden age of this genre. At that time, all major Greek and Arabic texts on dietetics were available to the European West in Latin translations. Some of them were established as basic textbooks in medical faculties, and some were, in contrast, new releases on the Latin book market. Many modern Western Europe authors, including even Guillem's colleagues from Montpellier, wrote their own regimina based on the Latin translations of authoritative texts. ${ }^{26}$ It can be assumed that Guillem knew these translations as well as the modern regimina of his colleagues. To be able to assess the degree of his authorial independence, we have chosen a range of sources that were dealt with by Wolfram Schmitt ${ }^{27}$ and Melitta Weiss Adamson, ${ }^{28}$ as this corpus covers all of the important texts of the regimen genre, and that at the same time may have been at Guillem's disposal in Montpellier. ${ }^{29}$ It was not important for Guillem himself to support his recommendations with references to a well-known authority. He explicitly mentions his sources in only two places. However, the comparative corpus of regimens contains some other sources from which Guillem drew inspiration, for both the structure and particular advice.

Guillem's regimen starts with a prologue in which the author refers to the very beginning of the first book of Colliget by Averroes ( $†$ 1192). ${ }^{30}$ Averroes' Al-Kullìa ât fi Al-tibb was made available in 1285 in a Latin translation by Bonacossa de Padua and was very quickly established at the Montpellier medical faculty. ${ }^{31}$ Following Averroes, Guillem first presents medicine as a practical discipline which, like any other practical discipline, has its subiectum, which is the human body; its forma (i.e. health); and its instrumenta (i.e. the regulation of the six res non naturales). ${ }^{32}$ The next part of the prologue (the division of

Another regimen that originated at about the same time and uses the words conservator sanitatis is the famous regimen by Konrad of Eichstätt - Hagenmeyer, Ch. (Ed., 1995).

25 For details on all areas of dietetics, see Gil-Sotres, P. (1996: pp. 111-394).

26 Regarding this theme, see, for example, Schipperges, H. (1964), (1976), (1981: pp. 173-196), (1982: pp. 151-176).

27 Schmitt, W. (2013), the comparison was made not only from those texts that Schmitt deals with analytically, but also with texts that are listed in the introductory overview of regimen sanitatis and that are time-relevant.

28 Weiss Adamson, M. (1995).

29 For the period up to the beginning of the 14th century, when Guillem's regimen was written, there are several dozen dietary texts that will not be listed here by name (only those where certain matches have been found will be listed in the appropriate place).

30 For this work, the edition Magni Averrois Cordubensis... Colliget, in Aristotelis Stagiritae Omnia quae extant opera, vol. IX. Venetiis: apud Cominum de Tridino Montisferrati, 1560, was used.

31 For more detail on this theme, see McVaugh, M. R. (2019: pp. 21-36).

32 The concept was introduced to medicine by Averroes, see Schmitt, W. (2013: p. 137). 
medicine into ars conservativa sanitatis and ars curativa egritudinis) is based on Galen's Tegni or Ars parva from the end of the 2nd century. ${ }^{33}$ Guillem undoubtedly knew an older anonymous Latin translation based on the Greek original from around the middle of the 12th century from southern Italy. ${ }^{34}$ In the following passage, however, it is evident that he also knew the commentary on Tegni by Alī Ibn Ridwān († ca 1061 or later), which was referred to as Comentum Haly and which accompanied the Arabic adaptation of Galen's Tegni. They were both translated by Gerhard of Cremona in the second half of the 12th century. In the Ars medicine - a collection of basic medical textbooks, later known as the Articella - from sometime around the middle of the 13th century, an anonymous Greek-Latin version of Tegni was combined with an Arabic-Latin version with commentary. ${ }^{35}$ Guillem apparently must have worked with this modern version of the Ars medicine. However, he discusses everything in his own words.

The first chapter, de aere convenienti, points to only two aspects that are important in the assessment of air - substancia and qualitas. The term substancia includes what we would today call air quality - its purity and freshness. The term qualitas is understood here in terms of four basic qualities (warm, cold, humid, and dry) and their effects on the human body, either in a balanced state, when the qualities are in balance (aer temperatum, corpus temperatum), or in a state when some qualities dominate (aer distemperatum). At the beginning of the chapter, Guillem refers to Galen's De regimine sanitatis (or De sanitate tuenda), which he knew as translated by Burgundio of Pisa. ${ }^{36}$ Formally, however, he was not inspired by this text (Galen here proceeds according to the individual stages of human life). ${ }^{37}$ It was not until 1340 that De regimine sanitatis became a compulsory part of the curriculum at the Faculty of Medicine in Montpellier, ${ }^{38}$ but there is evidence that it had been used there prior to that. ${ }^{39}$ In the following chapters, Guillem completely refrained from mentioning sources.

The second chapter, de motu et quiete, and the third chapter, de sompno et vigilia, are very well structured because the advice is given in numbered points (regule). In both chapters, we have managed to find a literal correspondence with the source text - for most of the regule, it was the Persian physician Rhazes ( $\uparrow 925)$, his fourth book in Liber

33 The basic tools for Galen's works are Corpus Galenicum (http://cmg.bbaw.de/online-publications/Galen-Bibliographie_2019-12x.pdf) and Galeno, Catalogo delle traduzioni latine (http://www.galenolatino. com/). The edition Galieni ... micro Tegni cum commento Hali Rodoham was used for a comparison with Guillem's text, in [Articella]. Venetiis: Hermann Liechtenstein, 1483, f. 151r-210r.

34 For this translation, see O’Boyle, C. (1998: p. 93); Ottosson, P.-G. (1984: p. 24).

35 O’Boyle,C. (1998: pp. 93-94, 138-139).

36 Galenus, De regimine sanitatis, in Galieni Opera, vol. II. Venetiis: per Philippum Pintium de Caneto, 1490 , f. 168v-181vb. The print does not have foliation, a digitilised copy, which is foliated by hand, is used here (https://www.biusante.parisdescartes.fr/histoire/medica/resultats $/$ index.php?do=chapitre\&cote $=$ extacadinca12). For this text, see Gil-Sotres, P. (1996: pp. 29-34).

37 Galen's procedure was used by many regimina authors (for example, Avicenna, Maino de Maineri, and Bernard of Gordon).

38 O’Boyle, C. (1998: p. 148, 149), regarding statutes in Montpellier, see Verger, J. (2004: pp. 13-28).

39 It is cited by Arnaldus deVilla Nova, or as already mentioned in footnote 37, Bernard de Gordon, cf. GilSotres, P. (1996: p. 30). 
ad Almansorem, ${ }^{40}$ which was translated by Gerard of Cremona in Toledo in 1175. Liber ad Almansorem was a highly valued teaching text in Montpellier at the beginning of the 14th century ${ }^{41}$ and also a popular source for regimen authors. ${ }^{42}$ Guillem used Rhazes' order of recommendations and made them clearer by numbering them and marking them all as regule. The use of regule is typical for texts written in Montpellier at that time, as seen in two famous regimens from the first decade of the 14th century - by Bernard of Gordon $^{43}$ in his Liber de conservacione vite humane and by Arnald de Villa Nova in Regimen sanitatis ad inclitum dominum regem Aragonum ${ }^{4}$ - in Arabic sources, the content is not structured in this way.

The fourth chapter, de cibo et potu, is divided into three sections - first, the amount of food is assessed, second, its quality (again in terms of the four primary qualities), and third, its ordo (how often to eat, when to eat, and in what order). The first part of this chapter is disrupted by a later interpolation. Guillem states what signs can be used to judge an excess of food and drink and, since the amount of faeces should match the amount of food eaten, the copyist inserted a passage on how to assess healthy faeces. This passage (in the edition it forms one paragraph) is introduced by the words Continuacio tamen nostra dat signum and is marked with a marginal line up to the notified signum, i.e. a cross that indicates the end of the inserted part. Then the text of the original regimen continues again.

The exposition of the middle part (on the topic of qualitas) is the longest. It is devoted to individual types of food and beverages (bread, wine, water, meat from four-legged animals, birds, fish, eggs, vegetables and herbs, fruits, and legumes), and then numbered regule concerning when and how a person should eat and drink are inserted illogically. These regule were also excerpted from Rhazes (treatise IV, chap. 4). Considering their content, they should belong to the third part, where some of these recommendations are repeated, albeit in other words. Rhazes was probably a source of information also for some other parts of the fourth chapter (carnes, volatilia, pisces, ova), where Guillem no longer excerpted the rules literally. These statements are so general and brief that we can only assume the Rhazes' influence since Guillem used this source for the preceding regule. In addition, he probably arranged the order of individual types of food and beverages according to Rhazes. This order is unusual in the context of regimina and is not found anywhere other than Rhazes. One particularity lies in the fact that the treatment of food is interrupted after the passage about bread by a discussion on drinks, specifically

40 Rhazes deals with dietetics in books III, IV, and VI (Guillem excerpted only Book IV). For the comparison, the following edition was used: Liber Rasis ad Almansorem. [Venetiis]: per Bonetum Locatellum Bergomensem 1497; Gil-Sotres, P. (1996: pp. 47-49); Ullmann, M. (1970: p. 128ff.) and Sezgin, F. (1970: p. 274ff). For the content of the books on dietetics, see Schmitt, W. (2013: pp. 115-123).

41 Dumas, G. (2015: p. 56, 57, footnote 48).

42 For example, Arnaldus de Villa Nova, Konrad von Eichstätt, and Maino de Maineri drew their inspiration from this source, see Weiss Adamson, M. (1995: p. 64).

43 Cf. Bernhardi de Gordonio ... Tractatus de conservatione vitae humanae. Ed. Joach. Baudisius: [Lipsiae apud J. Rhamba], 1570, pp. 58-59 et al. See e.g. Nicoud, M. (2007, pp. 186-208). 
wine and water (in Rhazes, in the opposite order of water and then wine), and then Guillem continues with meat from quadrupeds and birds. ${ }^{45}$ It is clear that Rhazes was an important source in the section on food and drink, and we can therefore surmise that the similarities in the content of the passages on meat, birds, fish, and eggs are not coincidental. Guillem's interest in this source is also evident from the fact that he uses it in the Informatio studentibus suis. ${ }^{46}$

In the fifth chapter, de inanicione et replecione, the author describes three kinds of waste - he defines superfluitates, which the body excretes; he mentions the way the excretion happens; and he emphasizes its significance. Finally, the sixth, most concise chapter lists the individual movements of the mind and outlines possible effects on the human body, probably according to Galen's work De morbo et accidenti ${ }^{47}$ which is recorded among the textbooks in Montpellier for 1309. ${ }^{48}$

The most extensive chapter is, as is common in regimina sanitatis, de cibo et potu, which occupies more than half of the entire text; in contrast, the shortest is de accidentibus anime. The remaining parts of the text, including the prologue, are of similar extents. All of the chapters are very concise in terms of the amount of information; the author even omits some topics in the field of dietetics which represent the standard content of regimina. In the passage aer continens, he does not generally talk about climate or the location of a place with respect to its altitude, distance, or proximity to the sea; he does not mention the cardinal points and the winds blowing from them; and so on. In the passage motus et quies, he writes nothing about massages and baths, and in the passage about inanicio et replecio there is no talk of sexual intercourse. The brevity of Guillem's regimen and its abandoning of theoretical explanations is not surprising if we look at his Informacio scolaribus suis, which the editors commented on with these words: "This level of concrete instruction sets Guillem's brief text apart from the great mass of recipe collections, as perhaps it was meant to do." 49 This characteristic is apt even in the case of his regimen - the brevity and simplicity was probably the author's intention; he had in mind the needs of students just penetrating this field of medicine (in the fifth chapter, he omits the topic of phlebotomy because hic queritur sermonis brevitas). Practical teaching was, moreover, a common part of studies at the medical school in Montpellier, which necessarily influenced the literary activities of its teachers. ${ }^{50}$ Specifically for Guillem, his practical focus can be read not only from the regimen and the Informacio and Documentum. Various recipes circulated under his name, ${ }^{51}$ and Guillem's possible authorship of the aforementioned Prague antidotarium, copied in Erfurt by Matthaeus Beran, should be recalled.

45 Cf. overviews of individual regimes at Weiss Adamson, M. (1995).

46 McVaugh, M. \& Martínez Gázquez, J. \& †García Ballester, L. (2003: p. 6).

47 Galenus, De morbo et accidenti, in Galieni Opera II., f. 154r-168r (see footnote 36).

48 O'Boyle, C. (1998: p. 148), Dumas, G. (2015: p. 57, footnote 148). For the reception of this treatise in Montpellier, see also Salmón, F. (2000: pp. 135-157).

49 McVaugh, M. \& Martínez Gázquez, J. \& †García Ballester, L. (2003: p. 7).

50 Demaitre, L. (1975: pp. 103-123), Dumas, G. (2015: pp. 180-186 et al.).

51 De la Rosa Cubo, C. (2002: p. 79 and 536). 


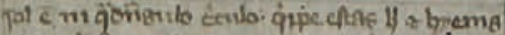

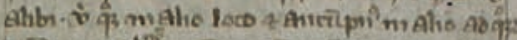

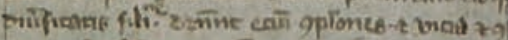

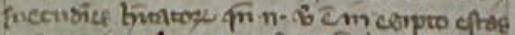

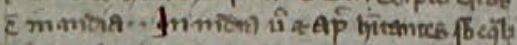

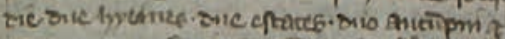

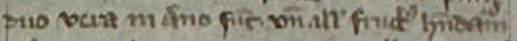

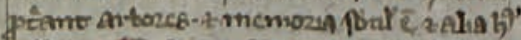

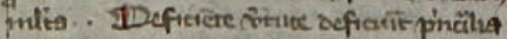

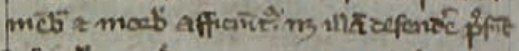

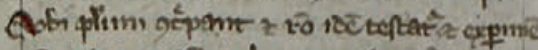

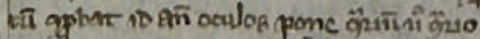

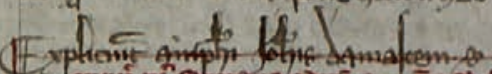

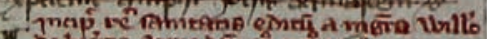

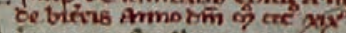

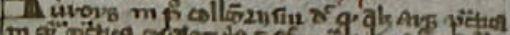

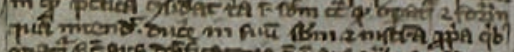

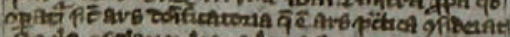

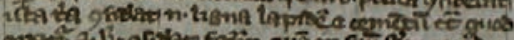

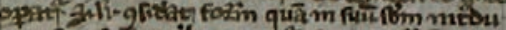

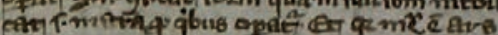

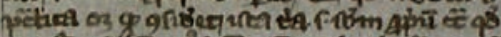

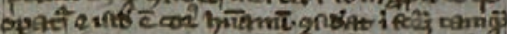

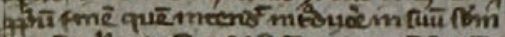

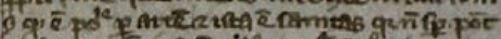

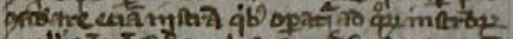

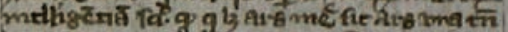

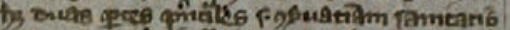

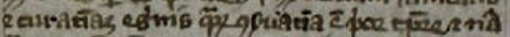

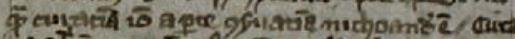

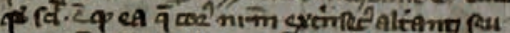

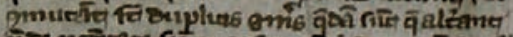

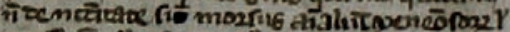

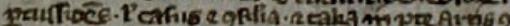

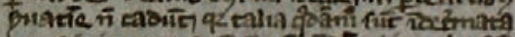

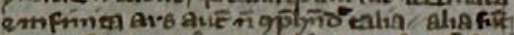

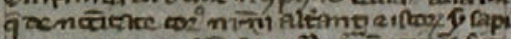

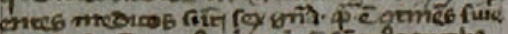

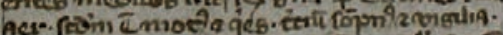

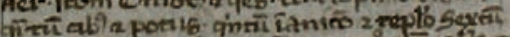

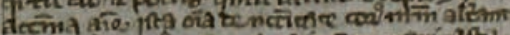

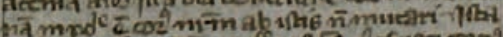

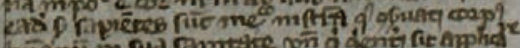

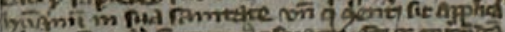

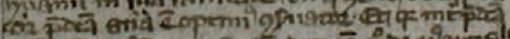
arî̀

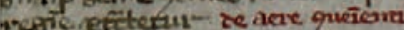

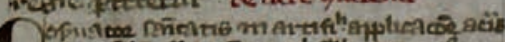

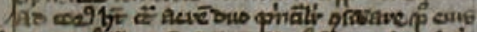

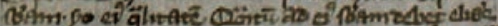

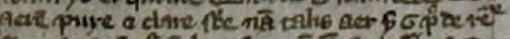

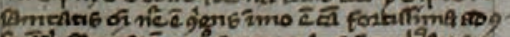

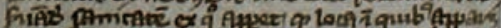

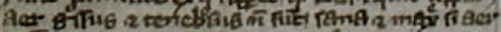

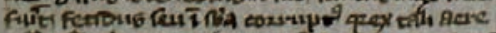

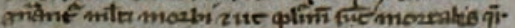

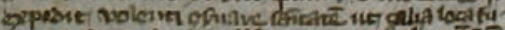

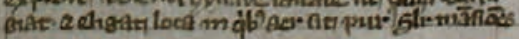

flic zomos

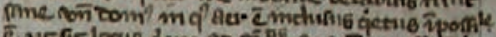

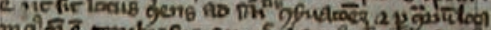
$m$ वी

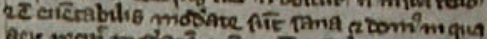

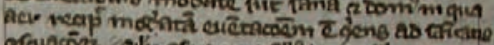

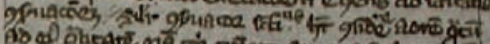

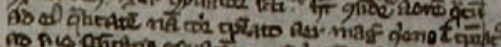

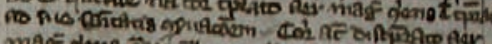

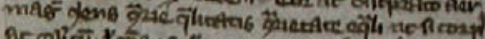

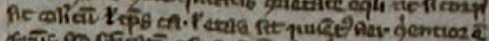

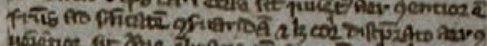

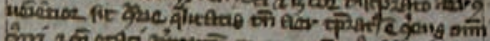

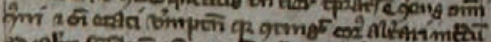

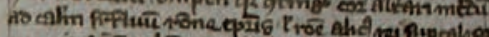

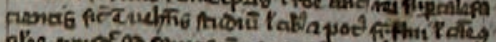

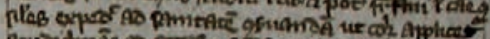

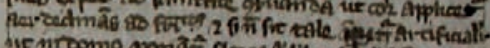

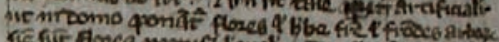

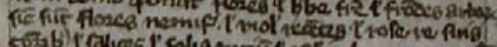

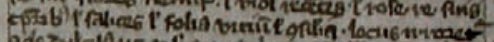

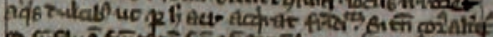

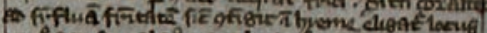

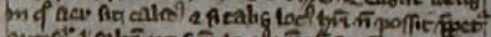

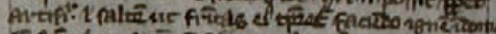

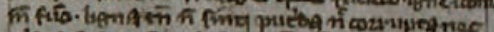

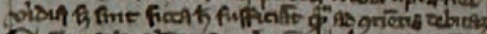

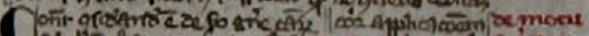

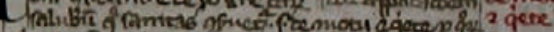

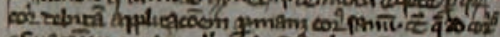

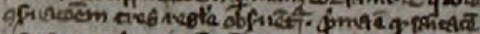

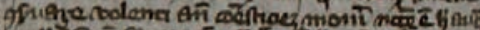

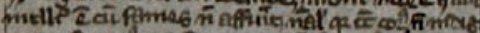

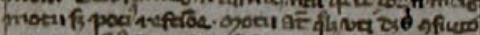
9. price ip

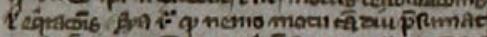

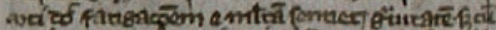

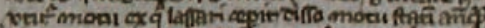

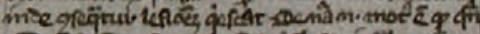

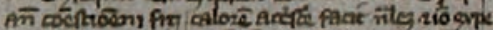

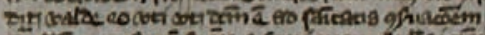

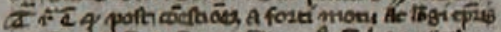

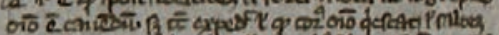

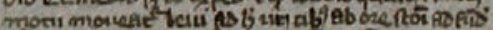

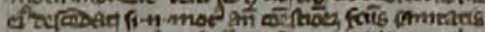

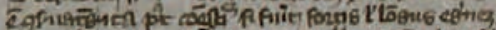

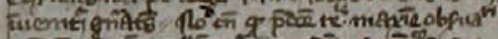

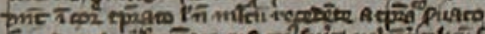

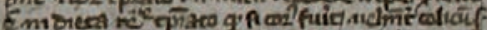

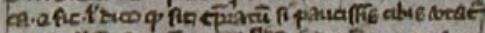

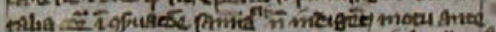

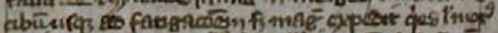

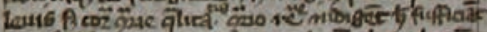

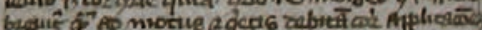

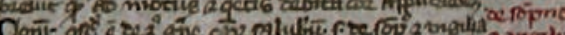

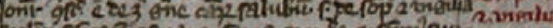

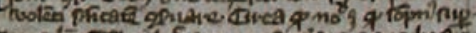

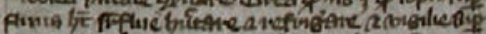

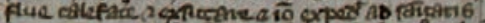

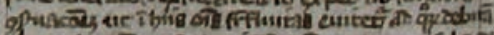

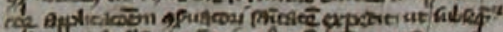

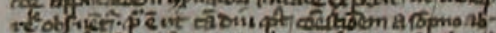

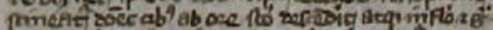

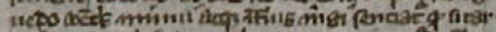

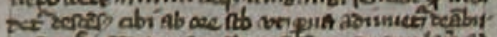

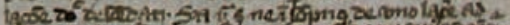

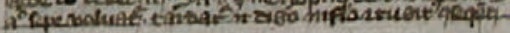

The manuscript of Regimen sanitatis, p. 21 (Museum and Gallery of the Eagle Mountains in Rychnov nad Kněžnou, Czech Republic) 
The differences from the examined corpus of regimina do not lie only in the general brevity and absence of some important topics that were traditionally associated with the six res non naturales. Another obvious difference is the order of the chapters - namely the inclusion of the passage on food and drink in the fourth chapter, following the section somnus et vigilia. As the statistical analysis of regimens by Melitta Weiss Adamson has shown, ${ }^{52}$ in the first two representatives of the genre regimen sanitatis, which were translated from Arabic and made available to the Latin West by Constantinus Africanus in the 11th century - in Isagoge Iohannitii ${ }^{53}$ from the 9 th century and in Pantegni ${ }^{54}$ by Haly Abbas from the 10th century - cibus et potus appears as the third section (after aer as the first and motus et quies as the second), and only after that follows the section somnus et vigilia. The highly influential regimen written by Avicenna in his treatise Canon medicinae discuss the section cibus et potus already second..$^{55}$ In later Western regimina, we can find both ordering approaches (as the second section and as the third) as well as the cibus et potus section as the first, which is due to the importance of this topic as also seen in the more thorough elaboration of this passage in comparison with other res non naturales. Guillem's unconventional placing of cibus et potus fourth thus goes beyond the usual processing of Arabic and later Latin regimina. Guillem was probably influenced by the order given by Galen in his Tegni - in the tenth chapter of the third book and in the following discussion in chapters $11-15,{ }^{56}$ where cibus et potus is mentioned fourth. ${ }^{57}$ The reason this order was not applied in other dietary texts is obvious. Johannitius' Isagoge, which is an introduction to Galen's Tegni ${ }^{58}$ and which was an important source for later regimina, did not reflect Galen's original order.

Another conspicuous feature of Guillem's regimen is his terminology. Instead of the common term res non naturales, which was used in the aforementioned Latin translations of Isagoge Iohannitii and Pantegni by Constantinus Africanus and domesticated in dietetics literature, Guillem exclusively uses the term causae salubres. This designation must have been well known to teachers in medical faculties as it appears in Galen's Tegni (in the older Greek-Latin translation from the mid-12th century), from which we already know Guillem drew inspiration, but we cannot find this term in the examined corpus of regimina sanitatis. ${ }^{59}$ Res non naturales are also referred to as causae only in the translations

52 See the statistical analysis in Weiss Adamson, M. (1995: pp. 191-192).

53 Regarding the content of the regimen section, see Schmitt, W. (2013: pp. 67-97), Weiss Adamson, M. (1995: pp. 39-41).

54 Regarding the content of the regimen section, see Schmitt, W. (2013: pp. 42-58), Weiss Adamson, M. (1995: pp. 42-49).

55 See note 24.

56 Cf. [Articella.] Venetiis: Hermann Liechtenstein, 1483, f. 184rb-va.

57 Regarding the concept and terminology of res non naturales in Galen's Tegni and his other works, see García-Ballester, L. (1993: pp. 105-114), Rather, L. J. (1968: pp. 337-347).

58 Regarding the order of res non naturales in Johannitius, see Schmitt, W. (2213: pp. 45-48).

59 Cf. the beginning of the third book: Quoniam vero et harum causarum quedam sunt salubres quedam egre, quedam neutre, primum de causis sanis sermo erit (Galieni ... micro Tegni cum commento Hali Rodoham III, 1. In [Articella.], 1483, f. 183rb, and also, e.g., Tegni III, 9, III, 18, III, 19, III, 25 et al. In the Arabic-Latin version Ars parva created in Toledo and apparently wrongly attributed to Gerhard of Cremona, the term 
of Avicenna's Canon medicinae and Averroes' Colliget, but there they are referred to as causae efficientes or causae neccessariae. ${ }^{60}$

The effort to identify sources for individual chapters was not remarkably successful. We know for sure that Guillem drew inspiration from Galen's Tegni; he was also acquainted with Ibn Ridwān's commentary on Tegni (Comentum Haly); he knew De regimine sanitatis (and perhaps De morbo et accidenti) from the so-called New Galen, ${ }^{61}$ Liber Almansoris by Rhazes, and Canon medicinae by Avicenna from corpus Toletanum; and he was familiar with Averroes' Colliget translated only in 1285. However, Guillem's advice is for the most part so common or general that a direct source cannot be found. We can see this in the example of Hippocrates' Aphorism II, 50, which advises people to follow their habits and, if in need of a change, to change slowly. For Guillem, this piece of advice was the most basic recommendation, which is repeated in the regimen in several places. This rule is repeated in Galen's commentary on Aphorisms, ${ }^{62}$ in Galen's Tegni (III, 33), ${ }^{63}$ in Pantegni (Practica I, 7) ${ }^{64}$ in Rhazes' Liber Almansoris (IV, 10), ${ }^{65}$ in Maimonides' regimen (I, 3), ${ }^{66}$ in Avicenna's Cantica $(2,1,17-18),{ }^{67}$ in a regimen sanitatis by Bernard of Gordon (II, 11), ${ }^{68}$ and elsewhere. Thus, for many of Guillem's recommendations, we find parallels in several if not all of the texts examined: one should eat what one likes and is accustomed to, even though it is less healthy than another healthier food one does not like; hard-working people should eat hearty meals and, conversely, people with effortless lifestyles should eat light meals; these should be eaten before heavy ones and not vice versa; strenuous movement after eating is not healthy; one should not drink immediately after a meal and before going to bed; in sleep, one should lie first on the right side,

causae sanitatis is used instead (cf. [Articella], 1483, f. 183rb). Regarding both translations, see O'Boyle, C. (1998: pp. 93-94).

60 For these designations, see Weiss Adamson, M. (1995: pp. 18-21) and Schmitt, W. (2013: pp. 126, 136).

61 For the so-called New Galen, see García Ballester, L. (1982: pp. 97-158).

62 [Articella], 1483, f. 19vb.

63 [Articella], 1483, f. 188va.

64 Liber Pantegni Ysaac Israelite... quem Constantinus Aphricanus... sibi vendicavit. In Omnia opera Ysaac. Lugdunum: Trot, 1515 , f. 60.

65 Liber Rasis ad Almansorem. [Venetiis] 1497, f. 19r.

66 Maimonides' regimen from the end of the 12th century was widespread in Latin versions, especially the translation of John of Capua, which was based on a Hebrew text. However, in order to compare it with Guillem's regimen, it was necessary to use the second Latin version, which was based on an Arabic text and was closely related to Montpellier. Armengaud Blasii, a nephew of Arnald de Villa Nova, worked on this second version in the first decade of the 14th century. It might have been the source that Guillem had at his disposal. Both Latin translations have recently been edited by Bos, G. (2019). Armengaud's authorship of the translation was questioned in the past, but a thorough linguistic analysis has shown that it is Armengaud's translation at least up to Chapter 3.10 (regarding this translation and the discussion of authorship, see ibid., pp. 242-251).

67 Avicennae Cantica... cum eiusdem Aver. Expositione, in Aristotelis Stagiritae Omnia quae extant opera, vol. IX. Venetiis 1560, f. 224v. Cantica with Averroes' commentary were translated into Latin by Armengaud Blasii of Montpellier in 1284.

68 Bernhardi de Gordonio ... Tractatus de conservatione vitae humanae. Ed. Joach. Baudisius, [Lipsiae apud J. Rhamba], 1570, pp. 65-71. 
then on the left; and so on. For this reason, in the critical edition of the regimen, it was necessary to refrain from stating content parallels with other regimina sanitatis, except in those places where the source is clearly evident or at least very probable.

As a student and later a teacher in Montpellier, Guillem was familiar with Articella, the New Galen, and the great compendiums of Arabic physicians. He was well acquainted with the instructions that were taught in Montpellier at the beginning of the 14th century and formulated them very simply, mostly in his own words. Undoubtedly, he also included his own experience and opinions in the text, which have no parallel in any of the compared texts (for example, he thoroughly discusses the mixing of wine with water). Nevertheless, we can observe a certain connection among the regimen texts of Guillem's time. To show the similarity of content, we will show two parallel places between Guillem's regimen and the regimen by Bernard of Gordon:

Guillemus de Biterris, Regimen sanitatis 4.2.2. Bernardus de Gordonio, De conservatione vitae humanae, 2,12 , p. $74-75^{69}$

Potus autem conveniencior ad sanitatem conservan- Calidi vero de complexione sumant vinum album dam ut plurimum et maxime viventibus in ocio debet in colore, et subtile in substantia, et cum temperaesse vinum clarum, subtile in substancia, odoriferum, ta quantitate aquae... Praeterea intelligendum quod album in colore vel modicum declinans ad quandam quando nos loquimur de vino, intelligimus optimo, citrinitatem... si fuerit corpus calidum... multa aqua scilicet quod ... sit vinum citrinum in colore, medioest miscenda cum vino, et maxime si fuerit forte vi- cre in substantia, odoriferum... qualia sunt quae cresnum, unde in conservacione sanitatis multum expe- cunt communiter circa Montem Pelum, et ut pluridit ministrare vina debilia corporibus calidis sicut mum in tota provincia Narbonensi...

vina gallicana...

Guillemus de Biterris, Regimen sanitatis, 6

Bernardus de Gordonio, De conservatione vitae humanae, 2, 15, p. 79

Nam conservator sanitatis debet vitare regulariter Vitetur ergo ira et sollicitudo et tristicia, quoniam accidencia anime corpus nostrum alterancia, sicut febrem inducit, phthisin, et mortem subitaneam, sicut est gaudium inmoderatum, quia sicut experiencia timor, gaudium nimium cum venit subito, mortem probatur, subitam mortem inducunt, sicut facit timor subitam inducit, secundum Galienum in de morbo et fortis. Similiter ira corpus superflue calefacit, simi- accidenti. Intelligendum tamen, quod gaudium temliter angustia et sollicitudines inmoderate... quare peratum competit omni aetati, et omni complexioni expedit volenti sanitatem conservare, uti gaudio et omni homini, nisi quando non vult impinguari, moderato et aliis consolacionibus anime, in quibus quoniam gaudium temperatum impinguat, secunanima delectatur. Si tamen medicus querat corporis dum Avicennam.

extenuacionem, sicut cum corpus fuerit nimis pingue, inducat corpori talia, per que anima solicitetur superflue et tristetur, neque talia accidencia habent corpus desiccare...

69 According to the edition in the previous footnote. 
The direct dependence of the two texts is not manifested here, but if we look at identical places in potential sources, it is more than clear that although Guillem and Bernard formulated their ideas independently, they are remarkably close to each other, sometimes even closer than to the text of Galen or Avicenna, if we stick to the examples mentioned above. It is no surprise that we encounter similar vocabulary and the same method of processing words and structuring text by people working in the same location, at the same time, and in the same profession (we have already talked about rules - regule). Besides, the topic of dietetics was certainly very attractive and widely discussed within the Montpellier community. ${ }^{70}$ It was Montpellier where Jacob ben Machir ibn Tibbon, known as Profatius Judaeus, collaborated with a Christian surgeon in a translation of Avenzoar's Liber de regimine et conservatione sanitatis from Arabic into Latin in 1299. ${ }^{71}$ Sometime around the first decade of the 14th century, the aforementioned Armengaud Blasii of Montpellier worked on a translation of Maimonides' regimen, ${ }^{72}$ and in 1308, the regimens of Bernard of Gordon (De conservatione vitae humanae) and Arnold of Villa Nova (Regimen sanitatis ad inclytum regem Aragonum) were completed. ${ }^{73}$ In the same year, at the initiative of Bernard, the Montpellier medical student Berenguer Eymerich translated a regimen for the sick by Abulcasis (De cibariis infirmorum). ${ }^{74}$ Guillem's regimen from 1319 is thus just further proof of the popularity of this genre in Montpellier at that time, and the content similarities that are sometimes found with older regimina of his contemporaries reveal the matrix in which Guillem's regimen originates.

\section{Bibliography}

\section{Primary sources (incunabula, old prints)}

[Articella.] Venetiis: Hermann Liechtenstein, 1483.

[Averroes.] Magni Averrois Cordubensis... Colliget. In Aristotelis Stagiritae Omnia quae extant opera, IX. Venetiis: apud Cominum de Tridino Montisferrati, 1560.

[Avicenna, Liber Canonis.] Liber canonis ... quem princeps Aboali Abincenni de medicina edidit. Venetiis: Petrus Maufer, Nicolò Contugo, 1483.

Avicennae Cantica... cum eiusdem Averois Expositione. In Aristotelis Stagiritae Omnia quae extant opera, IX. Venetiis: apud Cominum de Tridino Montisferrati, 1560.

Bernhardi de Gordonio ... Tractatus de conservatione vitae humanae. Ed. Joach. Baudisius, [Lipsiae: apud J. Rhamba], 1570.

70 Regarding regimina written in Montpellier, see, e.g., Nicoud, M. (2004: pp. 233-251).

71 Dumas, G. (2015: p. 98), Schmitt, W. (2013: pp. 155-162), Gil-Sotres, P. (1996: pp. 52-53); McVaugh, M. R. \& Bos, G. \& Shatzmiller, J. (2019).

72 See footnote 66 and Schmitt, W. (2013: pp. 141-145), Gil-Sotres, P. (1996: pp. 54-55).

73 In addition, Arnald wrote other regimina texts (De conservanda iuventute et retardanda senectute and commentary on Regimen sanitatis Salernitanum). For a brief overview of his work, see Salmón, F. (2004: pp. 133-143).

74 Dumas, G. (2015: p. 196). 
Comentum Haly. In [Articella]. Venetiis: Hermann Liechtenstein, 1483, f. 151r-210r.

Galenus, Tegni. In [Articella]. Venetiis: Hermann Liechtenstein, 1483, f. 151r-210r.

Galenus, De morbo et accidenti. In Galieni Opera, vol. II. Venetiis: per Philippum Pintium de Caneto, 1490, f. $154 \mathrm{r}-168 \mathrm{r}$.

Galenus, De regimine sanitatis. In Galieni Opera, vol. II. Venetiis: per Philippum Pintium de Caneto, 1490, f. $168 \mathrm{v}-181 \mathrm{vb}$

[Haly Abbas.] Liber Pantegni Ysaac Israelite... quem Constantinus Aphricanus... sibi vendicavit. In Omnia opera Ysaac. Lugduni: Trot, 1515.

Hippocrates, Aphorismi. In [Articella]. Venetiis: Hermann Liechtenstein, 1483, f. 9r-45v.

[Rhazes.] Liber Rasis ad Almansorem. [Venetiis]: mandato [et] expensis nobilis viri domini Octaviam Scoti civis Modoetiensis, per Bonetum Locatellum Bergomensem, 1497.

\section{Primary sources (modern editions)}

García-Ballester, L. \& McVaugh, M. R. (Eds., 1996). Arnaldi de Villanova Opera medica omnia. X.1. Regimen sanitatis ad regem Aragonum. Barcelona: Publ. de la Univ. de Barcelona.

Bos, G. (Ed., 2019). Maimonides, On the Regimen of Health: A New Parallel Arabic-English Translation. Ed. by Gerrit Bos. Leiden: Brill.

Hagenmeyer, Ch. (Ed., 1995). Das Regimen sanitatis Konrads von Eichstätt. Quellen - Texte - Wirkungsgeschichte. Stuttgart: Steiner.

\section{Secondary sources}

De la Rosa Cubo, C. (2002). Summa medicinae (Mad. Esc. M. II. 17). Estudio y edición crítica. Tesis de doctorado. Universitad de Valladolid. 2000. Alicante: Biblioteca Virtual Miguel de Cervantes. Demaitre, L. E. (1975). Theory and Practice in Medical Education at the University of Montpellier in the Thirteenth and Fourteenth Centuries. Journal of the History of Medicine and Allied Sciences 30, 103-123.

Demaitre, L. E. (1980). Doctor Bernard de Gordon: professor and practitioner. Toronto: Pontifical Inst. of Mediaeval Studies.

Doležalová, L. (2015). Sborníky Matouše Berana [Miscellanies of Matouš Beran]. In Dragoun, M. \& Doležalová, L. \& Ebersonová, A. (Eds.), Ubi est finis huius libri deus scit. Středověká knihovna augustiniánských kanovniků v Roudnici nad Labem [Medieval Library of Augustinian Canons in Roudnice nad Labem], (pp. 126-140). Praha: Scriptorium.

Dulieu, L. (1975). La médecine à Montpellier. I. Le Moyen Age. Avignon: Presses Universelles.

Dumas, G. (2015). Santé et société à Montpellier à la fin du Moyen Âge. Leiden: Brill.

García-Ballester, L. (1993). On the origin of the "six non-natural things" in Galen. In Kollesch, J. \& Nickel, D. (Eds.), Galen und das hellenistische Erbe. Vertragungen des IV. Internationalen GalenSymposiums (pp. 105-114). Stuttgart: Steiner.

Fichtner, G. (2019). Corpus Galenicum. Bibliographie der galenischen und pseudogalenischen Werke. Zusammengestellt von Gerhard Fichtner †, weitergeführt durch die Arbeitsstelle „Galen als 
Vermittler, Interpret und Vollender der antiken Medizin (Corpus Medicorum Graecorum)“ der Berlin-Brandenburgischen Akademie der Wissenschaften. Erweiterte und verbesserte Ausgabe 2019/12, cit. according to http://cmg.bbaw.de/online-publications/Galen-Bibliographie_201912x.pdf.

García Ballester, L. (1982). Arnau de Vilanova (c. 1240-1311) y la reforma de los estudios médicos en Montpellier (1309): El Hipócrates y la introducción del nuevo Galeno. Dynamis 2, 97-158.

Gil-Sotres, P. (1993). Le regole della salute. In Grmek, M. D. (Ed.) Storia del pensiero medico occidentale. I. Antichità e medioevo (pp. 399-438). Roma-Bari: Laterza.

Gil-Sotres, P. (1996). Els regimina sanitatis. In García-Ballester, L. \& McVaugh, M. R. (Eds.) Arnaldi de Villanova Opera medica omnia. X.1. Regimen sanitatis ad regem Aragonum (pp. 25-55). Barcelona: Publ. de la Univ. de Barcelona.

Gil-Sotres, P. (1996). La higiene medieval. In García-Ballester, L. \& McVaugh, M. R. (Eds.) Arnaldi de Villanova Opera medica omnia. X.1. Regimen sanitatis ad regem Aragonum (pp. 111-394). Barcelona: Publ. de la Univ. de Barcelona.

Jacquart, D. \& Troupeau, G. (Eds., 1980). Yūhannā Ibn Māsawayh (Jean Mesue), Le Li̛re des axiomes médicaux (Aphorismi). Genève: Droz.

Le Blévec, D. (Ed. 2004). L'Université de médecine de Montpellier et son rayonnement (XIII ${ }^{-}$XV $V^{e}$ siècles). Actes du colloque international de Montpellier (Université Paul-Valéry - Montpellier III), 17-19 mai 2001. Turnhout: Brepols.

McVaugh, M. R. (1993). Medicine Before the Plague: Practitioners and Their Patients in the Crown of Aragon, 1285-1345. Cambridge: Cambridge University Press.

McVaugh, M. R. (2019). Averroes comes to Montpellier. In Weill-Parot, N. et al. (Eds.), De l'homme, de la nature et du monde. Mélanges d'histoire des sciences médiévales offerts à Danielle Jacquart (pp. 21-36). Genève: Droz.

McVaugh, M. R. \& Bos, G. \& Shatzmiller, J. (2019) The Regimen sanitatis of “Avenzoar”. Stages in the Production of a Medieval Translation. Leiden: Brill.

McVaugh, M. \& Ferre, L. (2000). The Tabula Antidotarii of Armengaud Blaise and its Hebrew Translation. Philadelphia: The American Philosophical Society.

McVaugh, M. \& Martínez Gázquez, J. \& †García Ballester, L. (2003). Guillem de Béziers and His Informatio scolaribus suis. History of Universites 18 (2), 18-28.

Nicoud, M. (2004). Les régimes de santé de l'aire montpelliéraine: Affirmation et renouveau de l'ars diaetae au xive siècle. In: Le Blévec, D. (Ed.), L’Université de médecine de Montpellier et son rayonnement (XIII ${ }^{e} X V^{e}$ siècles). Actes du colloque international de Montpellier (Université Paul-Valéry - Montpeller III), 17-19 mai 2001 (pp. 233-251). Turnhout: Brepols.

Nicoud, M. (2007). Les régimes de santé au Moyen Âge : Naissance et diffusion d'une écriture médicale, $X I I I^{e}-X V^{e}$ siècle. Rome: École Française de Rome.

O'Boyle, C. (1998). The Art of Medicine. Medical Teaching at the University of Paris, 1250-1400. Leiden: Brill.

Ottosson, P.-G. (1984). Scholastic Medicine and Philosophy: A Study of Commentaries on Galen's Tegni (ca 1300-1450). Napoli: Bibliopolis.

Rather, L. J. (1968). The "Six Things Non-Natural". A Note on the Origins and Fate of a Doctrine and a Phrase. Clio Medica 3, 337-347.

Salmón, F. (2004) La obra médica de Arnau de Villanova en Montpellier, in: Le Blévec, D. (Ed.), 
L'Université de médecine de Montpellier et son rayonnement (XIII'-XVe siècles). Actes du colloque international de Montpellier (Université Paul-Valéry - Montpeller III), 17-19 mai 2001 (pp. 133-143). Turnhout: Brepols.

Sezgin, F. (1970). Geschichte des arabischen Schriftums. III: Medizin - Pharmazie, Zoologie - Tierheilkunde bis ca 430 H. Leiden: Inst. für Geschichte der Arab.-Islamischen Wiss.

Schipperges, H. (1964). Die Assimilation der arabischen Medizin durch das lateinische Mittelalter. Wiesbaden: Steiner.

Schipperges, H. (1976). Arabische Medizin im lateinischen Mittelalter. Heidelberg: Springer.

Schipperges, H. (1981). Die Rezeption arabisch-griechischer Medizin und ihr Einfluss auf die abendländische Heilkunde. In Weimar, P. (Ed.), Die Renaissance der Wissenschaften im 12. Jahrhundert (pp. 173-196). München: Artemis-Verl.

Schipperges, H. (1982). Zur Rezeption und Assimilation arabischer Medizin im frühen Toledo. In Baader, G. \& Keil, G. (Eds.), Medizin im mittelalterlichen Abendland (pp. 151-176). Darmstadt: Wissenschaftliche Buchg.

Schmitt, W. (1979). Gesundheitstheorien in Antike und Mittelalter. In Blohmke, M. \& Schipperges, H. \& Wagner, G. (Eds.) Medizinische Ökologie (pp. 18-35).

Schmitt, W. (2013). Medizinische Lebenskunst: Gesundheitslehre und Gesundheitsregimen im Mittelalter. Berlin: Lit.-Verl.

Sudhoff, K. (1917). Zur Schriftstellerei Bernhards von Gordon und deren zeitlicher Folge: Eine Handschriftenstudie. Archiv für Geschichte der Medizin, 10, 162-188.

Sudhoff, K. (1918). Beiträge zur Geschichte der Chirurgie im Mittelalter: Graphische und textliche Untersuchungen in mittelalterlichen Handschriften. II. Leipzig: Barth.

Thorndike, L. \& Kibre, P. (1963). A Catalogue of Incipits of Mediaeval Scientific Writings in Latin. Cambridge, Mass.: Mediaeval Acad. of America.

Tošnerová, M. (2001). Průvodce po rukopisných fondech v České republice. III. Rukopisné fondy muzeí a galerii v České republice [Guide to Manuscript Collections in the Czech Republic, III, Manuscript Collections of Museums and Galleries in the Czech Republic]. Praha: Archiv Akademie věd ČR.

Truhlář, J. (1905). Catalogus codicum manu scriptorum Latinorum, qui in C. R. Bibliotheca publica atque universitatis Pragensis asservantur. 1. Pragae: Regia societatis scientiarum Bohemica.

Tříška, J. (1992). Codices manu scripti medii aevi Richnovienses, Studie o rukopisech [Studies on manuscripts] 29, 137-144.

Ullmann, M. (1970). Die Medizin im Islam. Handbuch der Orientalistik. Erste Abteilung: Der Nahe und der Mittlere Osten. Ergänzungsband 6. Erster Abschnitt. Leiden: Brill.

Verger, J. (2004). Les status de l'Université de médecine de Montpellier. In Le Blévec, D. (Ed.), L'Université de médecine de Montpellier et son rayonnement (XIII ${ }^{e}-X V^{e}$ siècles). Actes du colloque international de Montpellier (Université Paul-Valéry - Montpeller III), 17-19 mai 2001 (pp. 13-28). Turnhout: Brepols.

Weiss Adamson, M. (1995). Medieval Dietetics: Food and Drink in Regimen Sanitatis Literature from 800 to 1400. Frankfurt am Main: Lang.

Wickersheimer, E. (1936). Dictionnaire biographique des médecins en France au Moyen Âge. I. Paris: Droz.

Wickersheimer, E. \& Jacquart, D. (1979). Dictionnaire biographique des médecins en France au Moyen Âge. III. Supplément. Paris: Droz. 


\section{Edition notes:}

The text is published from the only known manuscript, preserved at the Museum and Gallery of the Eagle Mountains in Rychnov nad Kněžnou (Muzeum a galerie Orlických hor v Rychnově nad Kněžnou) in the Czech Republic. The manuscript does not have any inventory number (its old, now invalid number was 440-C 5). The paper manuscript, written in the first half of the 14th century, consists of 12 unbound sheets. The published text is written on pages 21-23.

Several emendations have been made to make the text fluent and smooth - both copyist errors and errors undoubtedly made by the author of the text (e.g. anacolutha) have been corrected. Some of the author's stylistic awkwardness is left in the edition where it does not reduce the intelligibility of the text. Angle brackets $<>$ are used for editor's additions.

Section 4.1 is disrupted by an interpolation, the beginning of which is marked in italics (Continuacio tamen nostra dat signum) and the end with a cross.

The edition does not present bibliographic data on incunabula and old prints of Guillem's sources, which were consulted. They are included in the general list of sources and literature. An exception is Galen's De regimine sanitatis, which is not divided into chapters in the translation by Burgundio of Pisa. Due to the lack of structure in this text, it is referred to in the notes as the folio of the consulted incunabula. 
| Incipit regimen sanitatis editum a magistro Willelmo de Biterris anno domini $\mathrm{M}^{\circ} \mathrm{CCC}^{\circ} \mathrm{XIX}^{\circ}$

\section{$<$ Prologus $>$}

5 Averroys in primo Collectorii sui dicit, quod quelibet ars practica, inquantum practica, considerat tria, scilicet subiectum, circa quod operatur, et formam, quam intendit ducere in suum subiectum, et instrumenta propria, quibus operatur, sicut ars domificatoria, que est ars practica, considerat ista tria: considerat enim ligna, lapidem et cementum, circa quod operatur, similiter considerat formam, quam

10 in suum subiectum introducat, et instrumenta, pro quibus operatur. Et quia medicina est ars practica, oportet, quod consideret ista tria, scilicet subiectum proprium, circa quod operatur, et istud est corpus humanum. Considerat item formam tamquam proprium finem, quem intendit introducere in suum subiectum, secundum quod est possibile per artem, et ista est sanitas, quia non semper potest

15 considerare eciam instrumenta, quibus operatur. Ad quorum instrumentorum intelligenciam sciendum, quod licet ars medicine sit ars una, tamen habet duas partes principales, scilicet conservativam sanitatis et curativam egritudinis, quarum conservativa est prior tempore et natura quam curativa, ideo a parte conservativa inchoandum est. Circa quod sciendum est, quod ea, que corpus nostrum extrinse-

20 cus alterant seu conmutant, sunt duplicis generis. Quedam sunt, que alterant non de neccessitate, sicut morsus animalium venenosorum vel percussiones vel casus et consimilia. Et talia in parte artis conservative non cadunt, quia talia quodammodo sunt indeterminata et infinita. Ars autem non conprehendit talia. Alia sunt, que de neccessitate corpus nostrum alterant et istorum secundum sapientes medicos sunt sex genera. Primum est continens sive aer, secundum est motus et quies, tercium sompnus et vigilia, quartum cibus et potus, quintum inanicio et replecio, sextum accidencia anime. Ista omnia de neccessitate corpus nostrum alterant, nam inpossibile est corpus nostrum ab istis non mutari. Ista eadem secundum sapientes sunt medico instrumenta, quibus conservat corpus humanum in sua

30 sanitate, unde qui convenerit sic applicare corpori predicta genera, est optimus conservator. Et quia inter predicta genera primum genus est continens sive aer, ideo primo de eius artificiali regimine pertractetur.

\section{$<1>$ De aere convenienti}

35 Conservator sanitatis in artificiali applicacione aeris ad corpus habet circa aerem duo principaliter considerare, primo aeris substanciam, secundo eius qualitatem.

5-7 Averroys...operatur] cf. Averroes, Colliget I, 1 17-28 conservativam...mutari] cf. Galenus, Tegni III, $1-3,8,10$

$\mathbf{1 0}$ et em., scilicet ms. $\mathbf{1 6}$ quod em., q sine signo abbreviationis ms. 


\section{$<1.1>$}

Quantum ad eius substanciam, debet eligere aerem pure et clare substancie, nam talis aer secundum Galienum, primo De regimine sanitatis, omni nature est conveniens, immo est causa fortissima ad conservandum sanitatem. Ex quo apparet, quod loca, in quibus apparet aer grossus et tenebrosus, non sunt sana, et maxime si aer fuerit fetidus seu in substancia corruptus, quia ex tali aere generantur multi morbi et ut plurimum sunt mortales. Quare expedit volenti conservare sanitatem, ut talia loca fugiat et eligat loca, in quibus aer sit purus. Similiter mansiones | sive domus, in quibus aer non est moderate ventabilis, non sunt sane, unde domibus, in quibus aer est inclusus quietus, inpossibile est, ut sit locus conveniens ad sanitatis conservacionem. Et per contrarium loca, in quibus non est tenebrosus aer nec obscurus nec in substancia fetidus et est eventabilis moderate, sunt sana et domus, in qua aer recipit moderatam eventacionem, est conveniens ad sanitatis conservacionem.

$<1.2>$

Similiter conservator sanitatis habet considerare aerem, quantum ad eius qualitatem, nam corpori temperato aer magis conveniens est temperatus ad sue sanitatis conservacionem. Corpori autem distemperato aer magis conveniens contrarie qualitatis contrarietate equali, ut si corpus sit colericum vel tempus calidum vel etas sit iuventus, aer conveniencior est frigidus ad sanitatem conservandam. Et licet corpori distemperato aer conveniencior sit contrarie qualitatis, tamen aer temperatus est conveniens omni conplexioni et omni etati. Verumptamen quia contingit corpus alterari interdum ad calidum superfluum racione temporis vel racione alicuius rei supercalefacientis, sicut est vehemens studium vel cibus et potus superflui vel cause consimiles, expedit ad sanitatem conservandam, ut corpori applicetur aer declinans ad frigiditatem, et si non sit tale, preparetur artificialiter, ut in domo ponantur flores vel herbe frigide vel frondes arborum, sicut sunt flores nenufaris vel viole recentis vel rose rubre suis temporibus vel salices vel folia vicium vel consimilia. Locus irroretur aquis dulcibus, ut per hoc aer acquirat frigiditatem. Si tamen corpus alteretur ad superfluam frigiditatem, sicut contingit in hyeme, eligatur locus, in quo aer sit calidus, et si talis locus haberi non possit, preparetur artificialiter, vel saltem ut frigiditas eius temperetur faciendo ignem in domo sine fumo, ligna tamen non sint putrida nec corrupta nec viridia, sed sint sicca.

Hec sufficiant quantum ad continentis debitam corpori applicacionem.

2-4 Quantum...conveniens] cf. Galenus, De regimine sanitatis I, Opera II, Venetiis 1490, f. 169rb 18-20 corpori...equali] Galenus, De regimine sanitatis I, Opera II, Venetiis 1490, f. 169rb, cf. Galenus, Tegni III, 26-27

9 domus em., domos $m s$.

28-31 in...frigiditatem] cf. Comentum Haly III, 27 
<2> De motu et quiete

Consequenter considerandum est de secundo genere causarum salubrium, quibus sanitas conserventur, scilicet de motu et quiete, per quorum corpori debitam applicacionem permanet corpus sanum. Circa que ad corporis conservacionem 5 tres regule observentur.

Prima est, quod sanitatem conservare volenti ante comestionem moveri neccesse est. Hoc autem intelligendum est, cum fames non affuerit naturalis, quia tunc corpus non indiget motu, sed pocius refeccione. Motu autem quolibet uti debet sibi consueto, quod vires ipsius non excedat, vel sit motus deambulacionis 10 vel equitacionis.

Secunda regula, quod nemo motu tam diu presumat uti, donec fatigacionem et multam senciet gravitatem, sed cum utitur motu, ex quo lassari ceperit, dimisso motu statim, antequam inde consequatur lesionem, quiescat. De natura enim motus est, quod quando ante comestionem fit, calorem acrescere facit naturalem et

15 ideo expedit valde eo uti, ut dictum est, ad sanitatis conservacionem.

Tercia regula est, quod post comestionem a forti motu ac longi temporis omnino est cavendum, sed tunc expedit, vel quod corpus omnino quiescat vel saltem motu moveatur levi ad hoc, ut cibus ab ore stomachi ad fundum eius descendat. Si enim motus ante comestionem factus sanitatis est conservativus, ita post come-

20 stionem, si fuerit fortis vel longus, egritudinem invenitur generativus.

Notandum tamen, quod predicte regule maxime observari debent in corpore temperato vel non multum recedente a temperato, servato eciam in dieta regimine temperato, quod si corpus fuerit vehementer colericum, scilicet calidum et siccum, vel dico, quod sit temperatum, si paucissimis cibis utatur. Talia corpora

25 in conservacione sanitatis non indigent motu ante cibum usque ad fatigacionem, sed magis expedit quies vel motus levis, sed corpora contrarie qualitatis contrario regimine indigent.

Hec sufficiant breviter quantum ad motus et quietis debitam corpori applicacionem.

$<3>$ De sompno et vigilia

Consequenter considerandum est de $3^{\circ}$ genere causarum salubrium, scilicet de sompno et vigilia, volenti sanitatem conservare. Circa quod notandum est, quod sompnus superfluus habet superflue humectare et refrigerare et vigilie superflue

35 calefacere et exsiccare, et ideo expedit ad sanitatis conservacionem, ut in hiis omnis superfluitas evitetur. Ad quorum debitam corpori applicacionem conservatori sanitatem expedit, ut subsequentes regule observentur.

Prima est, ut tamdiu post comestionem a sompno abstineatur, donec cibus ab ore stomachi descenderit atque inflacio et gravedo ventris minui atque inferius

6-7 sanitatem...est ${ }^{1}$ ] RHAzes, Liber Almansoris IV, 2 8-10 Motu...equitacionis] ibid. 11-14 nemo... naturalem] ibid. 16-17 post...cavendum] ibid.19-20 Si...generativus] ibid.21-23 predicte...temperato] cf. Galenus, Tegni III, 26-27 34-36 sompnus...evitetur] cf. Comentum Haly III, 13 38-4,2 tamdiu... descendat] RHAZES, Liber Almansoris IV, 3 
mergi senciatur, quod si tardetur descensus cibi ab ore stomachi, ut parva adiuvetur deambulacione, donec descendat.

Secunda regula est, ne in sompno de uno latere ad aliud sepe volvatur. Tardatur enim digestio in stomacho et rugitus consequuntur. I

Tercia regula est, quod expedit, quod in sompno pulvinar sit altum, et precipue 5 si cibus ab ore stomachi non descenderit.

Quarta regula est: anima vigilare non cogatur, cum dissoluta et stupida fuerit, nam superflue vigilie corpus superflue calefaciunt et desiccant. Unde corpora sicca, quantum ad sanitatis conservacionem, magis debent declinare ad sompnum et quietem quam ad vigilias, corpora tamen plena et maxime flegmatica ad vigilias, corpora autem temperata mediocritatem in hiis debent maxime observare.

Quinta regula est, ut decubitus in principio sompni sit super dextrum latus, postea conpleta digestione, que per coniecturam quandam artificialem fit, super sinistrum. Nam per primum decubitum fit stomachi melior digestio, per secundum facilior transitus cibi digesti ad corpus a stomacho.

Sexta regula est, quod sompnus super dorsum non est conveniens in conservacione sanitatis, quia prohibet expulsionem superfluitatum a cerebro, racione cuius prohibicionis egritudines pessime generantur.

In talibus tamen, quid consuetum est, observetur, vel saltem si quid est consuetum et sit inconveniens, paulative ad id, quod melius est, transmutetur. Predicte regule sunt convenientes, quantum ad sanitatis corporalibus observacionem. Utrum autem expediant quantum ad anime sanitatem, discrecio cuiuslibet contra diiudicet, et maxime ille, qui habet regimen animarum.

$<4>$ De cibo et potu

Sequitur de $4^{\circ}$ genere causarum salubrium, scilicet de cibo et potu. Unde conservator sanitatis circa eorum debitam administracionem habet tria considerare: quantitatem, qualitatem et ordinem ipsorum.

\section{$<4.1>$}

Circa quantitatem ipsorum considerandum, quod quantitas offerendorum precisa certis literis scribi non potest, ut ego possim scire cum certitudine, quid corpori detur tantum de cibo, et non plus, puta unam libram panis, et non plus verum est. Secundum quandam quantitatem artificialem coniecturacionem nos inquirimus quantitatem considerando ad resolucionem corporis et tenorem ventris. Nam si corpus multum resolvatur et virtus sit sufficiens ad digerendum, datur plus de cibo, si contrarium est, contrarium sit. Propter quod fossores vel alias artes laboriosas

3-4 ne...consequuntur] ibid.5-6 pulvinar...descenderit] ibid. 7-8 anima...desiccant] ibid.8-11 Unde... observare] $c f$. ibid. 12-14 decubitus...sinistrum] cf. Avicenna, Canon medicinae lib. I, fen III, doctr. 2, cap. 7 16-18 sompnus...generantur] cf. ibid., cap. 9

5 pulvinar $e m$., pluinar $m s$. 
exercentes, si eorum sanitas debet congrue observari, indigent magna quantitate ciborum, viventes autem in ocio per conparacionem ad illos indigent paucis cibis. Verum est tamen, quod pueri et illi, qui sunt in augmento racione etatis, indigent multo cibo, quia in eis fit magna resolucio et virtus digestiva cum hoc est fortis prop-

5 ter fortitudinem caloris naturalis, qui est in eis, eciam quia cibus non solum datur racione deperditi, sed eciam augmenti. Unde medicus, qui est conservator sanitatis, volens considerare, si cibi et potus in quantitate sufficienti corpori applicentur vel insufficienti, oportet considerare signa, quibus predicta congnoscantur, scilicet si post cibum stipticum non senciatur in ventre tencio nec inflacio nec rugitus vel in

10 ore eructuacio nec superflua ventositatum generacio neque appareat circa regionem stomachi superfluus sudor, quia fatigacio virtutis digestive primo ex tali sudore ostenditur. Quando ista accidencia non sunt, ostenditur, quod non sit superflua quantitas, sed quando aliquid de predictis adest, superflua quantitas designatur.

Continuacio tamen nostra dat signum: Consideratur superfluitas prime digestionis,

15 que est egestio, quantum ad quantitatem, scilicet quantum ad eius qualitatem, substanciam et horam. Quantum ad quantitatem, si egrediatur secundum quantitatem ciborum sumptorum. Quantum ad eius qualitatem, ut retineat colorem naturalem, qui quidem color si fuerit naturalis, est declinans ad modicam citrinitatem, et quod non sit privata fetore, sed retineat aliquid de fetore, nam odor talis est odor ege-

20 stionis naturalis. Quantum ad substanciam, ut non sit nimis dura nec nimis mollis, sed sit in substancia mediocri et partes continue. Et conmendo, quod talis egestio signat digestionem perfectissimam. Illud non apparet in sua totali perfeccione in corporibus lapsis sanis, unde ad signandum digestionem in quolibet corpore sano esse bonam oportet in quolibet corpore considerare egestionem suam naturalem.+

25 Resolucio corporis ostenditur ex signis subsequentibus, scilicet considerando etatem, conplexionem, tempus, regionem et disposicionem aeris presentem et regimen. Nam si etas fuerit iuventus vel adolescencia et conplexio colerica fuerit et habitudo corporis rara cum carnis mollicie et tempus, regio et disposicio aeris presens sit calida et ars eius sit laboriosa, predicta signant, quod in corpore ma-

30 gna fit resolucio, et ideo plus de cibo dandum est. Si tamen virtus semel magnam quantitatem cibi tollerare nequeat, detur pluribus vicibus. Si autem sit contrarie, contrarium regimen observetur.

\section{$<4.2>$}

35 Secundo conservator sanitatis considerare debet ciborum qualitatem, unde corpori temperato cibi et potus temperati debent exhiberi, corpori tamen distemperato cibi et potus contrarie qualitatis. Si corpus ad meliorem sanitatem

14-21 Consideratur...continue] cf. MAINO DE MAINERI, Compendium regiminis sanitatis, ms. Paris, Arsenal 873 (XV), f. 18v-19r (editum in Arnaldi de Villanova Opera medica omnia, p. 291, adnotatio 5) 36 corpori...exhiberi] $c f$. Galenus, Tegni III, 38

14-24 Continuacio...naturalem+] signum scriptoris in margine (linea cum cruce in fine partis additae) 
debeat permutari, non eadem conservari, sed universalis consideracio vana est, nisi particularis applicetur.

\section{$<4.2 .1>$}

Expedit volenti conservare sanitatem, ut cibi et potus corpori convenientes considerentur, et primo, qualis panis conveniat. Sciendum est, quod panis, quo ut plurimum est utendum, est panis factus de tritico albo, collecto ex terris lapidosis, non pinguibus, et quod sit rarus, bene decoctus, levis, I a furfure bene mundatus, habens fermenti et salis sufficientem mixtionem, et quod non sit nimis vetus, sed sit unius diei. Sed panis cum contrariis disposicionibus regulariter non conpetit in conservacione sanitatis. Verum est tamen, quod habentibus constipatum ventrem magis conpetit panis furfureus. Similiter habentibus fortem calorem, sicut in exercitantibus forti exercicio sicut fossores, conpetit eciam magis panis conpactus, sed iuvenibus in ocio regulariter conpetit panis, qui superius descriptus est.

\section{$<4.2 .2>$}

Potus autem conveniencior ad sanitatem conservandam ut plurimum et maxime viventibus in ocio debet esse vinum clarum, subtile in substancia, odoriferum, album in colore vel modicum declinans ad quandam citrinitatem. Sed vina grossa, maxime dulcia et nova substancia turbida, talia sunt vitanda et vina multum antiqua et media sive acetosa. Verum est eciam, quod corporibus consumptis et habentibus latas venas non opilatas convenienciora sunt vina grossa rubea et dulcia sunt corporibus multum calidis conveniencia et vina viridia.

Notandum eciam, quod in conservacione sanitatis aqua miscenda est cum vino. Mixtio diversificatur secundum diversitatem vinorum et corporis disposicionem et congnicionem particularium, puta temporis, etatis, conplexionis. Nam si vinum sit debile, parum est miscendum de aqua, immo in flegmaticis vel senibus, maxime in tempore fridido, ponit sibi vinum sine aqua, immo non solum istud, sed eciam aliud, et maxime si stomachus fuerit flegmaticus et caput forte.

Similiter variatur mixtura aque cum vino secundum varietatem disposicionum corporis. Nam si fuerit corpus calidum, et maxime si stomachus fuerit talis et caput debile, multa aqua est miscenda cum vino, et maxime si fuerit forte vinum, unde in conservacione sanitatis multum expedit ministrare vina debilia corporibus calidis sicut vina gallicana. Advertendum, quod quedam sunt corpora, in quibus potus aque esset conveniencior quam vina pura, corpora multum calida, et maxime si habuerint stomachum et epar multum calidum, dum tamen non consumpta, et hoc maxime verum est in regionibus calidis et maxime assuetis.

Tercio varianda est mixtura aque cum vino secundum varietatem temporis et disposicionis presentis et aeris et regionis, nam si tempus fuerit calidum et 
presens disposicio aeris sit calida et ille sit studiosus vel negociis sollicitus et utatur arte laboriosa, oportet, quod multa aqua cum vino conmisceatur. Si autem assint contraria, contrarium fieret.

Et quia aqua optima est cum vino conmiscenda et eciam cum simili aqua cibaria

5 sunt paranda, expedit conservatori sanitatis congnoscere signa, quibus optima aqua congnoscitur. Circa quod notandum est, quod $4^{\text {or }}$ sunt signa principaliter, quibus eligitur optima aqua. Primum est, quod non sit in substancia turbata; secundum, quod non appareant in ea corpora terrestria; tercium, quod nullum habeat saporem extraneum; $4^{\mathrm{m}}$ quod cito calefiat et infrigidatur. Ista sunt signa su-

10 per bonitatem aque. Alia signa sunt falsa preter ista et fallunt. Et ideo regulariter aque foncium, que fluunt versus orientem et colantur per poros quosdam vel per terram mediam, sunt aque meliores, quia aque tales cito calefiunt et infrigidantur. Sed aque, que fluunt versus septentrionem non sunt bone, quia sunt grosse, unde nec cito calefiunt nec infrigidantur.

\section{<4.2.3>}

Consequenter considerandum est, quod carnes sunt convenientes in regimine sanitatis, et primo quadrupedum, unde carnes eduline, vituline, caprioline, cuniculi, lepores iuvenes suis temporibus, carnes arietine iuvenes. Omnes carnes

20 predicte et maxime viventibus in ocio sunt convenientes in regimine sanitatis, tempore tamen calido extremitates porci iuvenis sunt eciam convenientes. Verum est tamen, quod habentibus stomachum calidum vel utentibus artibus laboriosis expedit eis dare magis carnibus uti grossioribus, quia carnes subtiles in eorum stomacho defacili corrumpuntur propter fortitudinem caloris, qui in eis est.

\section{$<4.2 .4>$}

Volatilia in regimine sani conveniunt ut plurimum et maxime in ocio viventibus sicut pulli, perdices iuvenes suis temporibus, fasiani, capones et galline iuvenes. In tempore frigido pulli collumbarum, qui incipiunt volare, sunt eciam convenientes

30 satis in tempore temperato. In temporibus tamen calidis non expedit multum uti, quia sanguinem nimis calidum generant nec eciam eadem racione avicule agrestes et coturnices tamen a sapientibus laudantur. Predictis tamen carnibus potest quis uti vel elixis vel assatis vel in pastillo decoctis cum salsis convenientibus iuxta qualitatem corporis et disposicionem temporis. Nam in estate est utendum

35 agresta simplici vel succo limonum vel succis fructuum consimilium, et maxime si corpus fuerit superflue calidum. In temporibus tamen frigidis est utendum salsis cum bonis speciebus sicut cum cinamomo et gariofilis et cum similibus speciebus.

11-12 aque...infrigidantur] $c f$. GAlENus, De regimine sanitatis 1, Opera II, Venetiis 1490, f. 169rb 27 Volatilia...viventibus] $c f$. RHAZES, Liber Almansoris III, 10

4 quia] quia de $m s$. 
Aves degentes in aquis non sunt convenientes, caro enim salsa inconveniens existit, verumptamen corpori habundante flegmatica humiditate, et maxime in stomacho, conveniens est uti salsis carnibus vel piscibus salsis, non viscosis, modica quantitate tamen sumptis.

$\langle 4.2 .5>$

Pisces tamen ad conservacionem | sanitatis non sunt multum convenientes, generant sanguinem frigidum et humidum. Verumptamen in corporibus calidis et siccis interdum sunt convenientes, dum tamen fuerint boni pisces scamosi, habentes substanciam frangibilem, vel sint fluviales vel marini, dum tamen sint capti in flumine mundo, petroso vel arenoso, concurrenti vel in mari, et maxime in profundo. Pisces autem viscosi, male substancie, sunt mali et omnes tales ideo sunt vitandi. Uti autem potest eis vel in craticula assatis vel elixis et decoctis in aqua cum petrosilino vel feniculo vel salvia vel consimilibus herbis et sumantur cum salsa facta cum speciebus bonis, et maxime si tempus non fuerit calidum nec corpus fuerit superflue calidum.

\section{$<4.2 .6>$}

Ova lixa tremula regulariter sunt multum conveniencia in regimine sanitatis, sed assata vel dura sunt multum inconveniencia.

$<4.2 .7>$

Appetitus autem in omnibus istis semper est considerandus, ut assumatur ille cibus, in quo appetitus magis delectatur, dato quod non sit cibus laudabilis, dum tamen eius malicia multum non excedat. Similiter consuetudo in omnibus est multum consideranda, nam ea, que consueta sunt, minus ledunt quam inconsueta, licet sint deteriora et ideo non est mutanda consuetudo, et si fiat, paulative hoc fiat.

\section{$<4.2 .8>$}

Olera vel herbe in conservacione sanitatis non sunt sane, quia sanguinem aquosum generant ut plurimum, nisi tamen racione medicine. Unde conpetere possunt interdum ad ventris laxacionem vel ad alterandum corpus superflue calefactum vel infrigidatum vel opilatum, sicut uti expedit spinargiis vel borraginibus, bletis, atriplicibus, malvis, mercurialibus ad mollificendum ventrem. Sed lactuce, portulace, cucumeres ad alterandum corpus superflue calefactum, petrosilinum cum feniculo, sparago, menta, ysopo, salvia ad alterandum corpus superflue infridigatum vel ad provocandum urinam vel ad apperiendum vias, quo multum conpetit in regimine sanitatis.

1 Aves...convenientes] cf. ibid. 12-13 Pisces...vitandi] cf. ibid. III, 1620 dura...inconveniencia] cf. ibid. III, 14 23-25 Appetitus...excedat] $c f$. Hippocrates, Aphorismi II, 38 25-27 Similiter...deteriora] $c f$. ibid., II, 5027 non...fiat $^{2}$ ] $f$. RHAZES, Liber Almansoris IV, 10 


\section{$<4.2 .9>$}

Similiter ad conservadum sanitatem non conpetunt fructus regulariter racione cibi, solum in racione tamen medicine magis conpetunt. Aliqua ad mundificandum ventrem vel ad alterandum stomachum superflue calefactum, et tunc debent

5 sumi in principio comestionis, sicut sunt pruna, cerasa, ficus, fructus tamen in estate recentes, in hyeme sicce. Aliquando fructus conpetunt ad conprimendum cibum ab ore stomachi ad eius fundum, et tunc debent sumi in fine comestionis, sicut pira, coctana vel poma habencia quandam stipticitatem. Vel si interdum sit corrupta digestio in stomacho, sicut quod apparet de eructuacione fetida vel fu-

10 mosa, tunc valde conpetunt post cibum grana pomi granati mixta cum pellicula interiori et talis sumpcio multum corrigit corrupciones in stomacho.

\section{$<4.2 .10>$}

Legumina ad observandum sanitatem regulariter non sunt sana, brodiis tamen

15 eorum uti est conveniens, cum apperitivam habeant virtutem, cibo vero frigido de granis utendum est interdum, scilicet ordeato, avenato et maxime ordeato, cum corpus sencietur ad calorem maxime alteratum, cibo facto ex rizi vel tritico expedit uti magis habenti fortem calorem naturalem.

\section{<4.2.11>}

Advertendum, quod circa cibi administracionem debitam observande sunt alique regule generales volenti suam sanitatem observare.

Prima est, postquam fex inferius descenderit et pars ventris inferior lenis, in qua nulla remansit retencio, et motus precesserit, comedere est conveniens.

25 Secunda regula est, quod postquam appetitus affuerit, comestio non tardetur $<\mathrm{ab}$ eo>, qui se regit regimine convenienti.

Tercia regula est, quod non tantum comedat, quod suo appetitui satisfaciat omnino, immo aliquid de appetitu remaneat, nisi corpus fuerit temperatum.

Quarta regula est, quod summo opere est observandum, quod cibi consueti

30 sumantur et tociens edat, quociens consuevit, nisi consuetudo fuerit perniciosa, a qua paulative est transmutandum ad meliorem.

Quinta regula est, quod cuiuscunque hominis consuetudo est querenda, qualis enim cibus est conveniens, sit interrogandum. Sepe enim contingit, quod cibaria, que sunt mala aliquibus, reperiuntur aliis conveniencia, a quibus sicut ab aliis ca-

35 vere non debent. Si enim cibaria aliquibus conveniencia, que ipsi appareant, licet minus bona fuerint, tamen tribuenda sunt.

23-24 postquam...conveniens] ibid. IV, 4 25-26 postquam...eo] ibid. 27-28 non...temperatum] $c f$. ibid.29-31 summo...meliorem] ibid.32-36 cuiuscunque...sunt] ibid.

34 aliis] alliis $m s$. 
Sexta regula est, quod omnino illa, per que corrumpitur digestio, sunt vitanda, sicut multi cibi et diversi in cena sumantur, et maxime carnes et pisces et cibus grossus, quando ante subtile sumitur, et multitudo offarum in iure factarum vel in vino. Similiter quando multa existit mora inter principium prandii et finem.

$<4.2 .12>$

Circa regimen potus quedam regule speciales sunt observande. Prima est, quod si aliquis siciat in introitu lecti, aut sitit siti quodammodo intollerabili, aut tollerabili. Si tollerabili, distinguitur: aut precessit sufficiens potus iuxta quantitatem assumptorum ciborum, aut non. Si vero precessit sufficiens potus, sompnus mitigabit talem sitim. Si fuerit quodammodo intollerabilis, distinguendum est sicut prius: aut non precessit sufficiens potus iuxta quantitatem assumptorum ciborum, p. $23 b$ tunc sufficienter est bibendum, si sufficiens potus precessit, I sumatur aqua in modica quantitate sorbendo eam vel vinum valde mixtum solum ad mitigandum sitim, ut sit tollerabilis, quia sompnus eciam mitigabit. Omnino eciam eadem disposicione consideranda, quando aliquis sitit inter duas comestiones.

Secunda regula, que circa potum est observanda, quod super mensam non bibatur nisi modicum ad sitis mitigacionem, in fine sumatur pocius iuxta quantitatem assumptorum.

$<4.3>$

Tercio circa exhibicionem ciborum artificialiter ordo debet considerari. Circa ordinem tria conprehenduntur: primo, quociens dandum sit; secundo, qua hora; tercio, quo ordine sumantur.

Circa ista considerandum, quod attendendum est ad corporis conplexionem. Sufficit corpori flegmatico semel refici in die, naturali colerico autem bis, corpori autem temperato ter inter duas dies. Verum est tamen, quod quoad vices consuetudo est observanda, nisi perversa fuerit, a qua paulative est ad meliorem transmutandum, sicut prius dictum est.

Ordo eciam in sumendo cibos, sicut dictum est, conservetur, ut subtilia precedant grossa. Ordo autem, qui servari debet in sumendo potum, est iste: scilicet potus non sumatur, nisi post comestionem, et sumatur secundum quantitatem assumptorum. Verum est tamen, quod si sitis affuerit, bibere expedit, sed bibere solum ad mitigacionem sitis.

Hora autem conveniens est ad refeccionem, cum appetitus affuerit ei, qui regit se regimine temperato, sicut prius dictum est.

Circa ordinem sumendi cibum et potum et circa horam semper consuetudo est attendenda, eo modo, quo prius dictum est.

1-2 per...sumantur] ibid. 2-4 cibus...finem] ibid. 8-15 si...mitigabit] $c f$. Avicenna, Canon medicinae, lib. I, fen III, doctr. 2, cap. 8 17-19 super...assumptorum] $c f$. ibid., cap. 7 27-29 quoad...transmutandum] Rhazes, Liber Almansoris IV, 4 30-11,2 Ordo...attendenda] cf. ibid. 
$<5>$ De inanicione et replecione

Consequenter considerandum est de $5^{\circ}$ genere causarum salubrium, ex cuius debita applicacione ad corpus sanitas conservatur, scilicet de inanicione et replecione. Circa quod sciendum est, quod ista valde debent considerari volenti 5 sanitatem conservare.

Circa replecionem sciendum, quod ex cibis et potibus, quantumcunque sint laudabiles, inmoderate sumptis $3^{\text {a }}$ genera superfluitatum causantur vel generantur, secundum quod sunt tres digestiones. Prima est superfluitas grossa et terrestris et ista est prime digestionis, que fit in stomacho. Secunda est superfluitas aquosa,

10 que est secunde digestionis. Tercia est superfluitas fumosa et subtilis et est tercie digestionis. Prima superfluitas expellitur per secessum, et ideo ante cibum cottidie invitari natura ad expellendum superfluitatem grossam corpus movendo. Secunda superfluitas expellitur per vias urinales, et ideo valde salubre est uti ad expellendum superfluitatem aquosam cum rebus urinam provocantibus sicut

15 feniculo, sparago, brodiis cicerum et petrosillino, cum urine quantitas fuerit diminuta. Tercia superfluitas est fumosa et est tercie digestionis. Ista autem superfluitas expellitur per exercicium vel balnea aquarum moderate calidarum vel per stuphas vel fricaciones. Verum est, quod ex aliqua eius parte multum terrestris natura generat pilos et ungues, unde in conservacione sanitatis summe expedit,

20 quod corpus nostrum cottidie ab istis superfluitatibus mundetur, ex qua mundificacione corpus in continua sanitate conservabitur, quoniam ut plurimum omnes egritudines generantur ex retencione istarum superfluitatum, nam iste superfluitates retente vias opilant, poros claudent, ex quibus egritudines putridinales generantur maxime. Unde circa expulsiones istarum superfluitatum volenti sanitatem

25 conservare summum studium est habendum. Advertendum tamen, quod interdum bono regimine non servato excrescunt et superflua quantitas sanguinis et humorum. Quare faciunt corpus nostrum, et tunc si mali humores habitent corpus, cum medicinis apropriatis humori superfluo mundificetur levibus, tamen debita corporis preparacione precedente. Si autem sanguis cum humore habundaverit,

30 cum flebotomia minuatur. Loqui autem de ista naturali disposicione sufficienter non est intencio scribentis in hoc opere, cum per hoc sermo multum prolongaretur, et hic queritur sermonis brevitas. Sed consilium est, tunc a prudenti medico et non ab alio consilium salubre requiratur.

Circa inanicionem advertendum, quod cum corpus fuerit inanitum, cibis et 35 potibus convenientibus in modica quantitate acceptis est replendum, de quibus superius fecimus mencionem.

29 corporis] em. corpori $m s$. 
$<6>$ De accidentibus anime

Sextum genus causarum salubrium est considerandum volenti sanitatem conservare, que sunt accidencia anime. Nam conservator sanitatis debet vitare regulariter accidencia anime corpus nostrum alterancia, sicut est gaudium inmoderatum, quia sicut experiencia probatur, subitam mortem inducunt, sicut facit timor fortis. Similiter ira corpus superflue calefacit, similiter angustia et sollicitudines inmoderate, nam talia corpus nostrum superflue desiccant, quare expedit volenti sanitatem conservare, uti gaudio moderato et aliis consolacionibus anime, in quibus anima delectatur. Si tamen medicus querat corporis extenuacionem, sicut cum corpus fuerit nimis pingue, inducat corpori talia, per que anima solicitetur superflue et tristetur, neque talia accidencia habent corpus desiccare. Verum est tamen, quod ut plurimum in regimine expedit uti gaudiis moderatis et placeat altissimo, ut eis taliter uti valeamus, ut pervenire possumus ad gaudia sapientis. Amen. Explicit.

doc. Mgr. Dana Stehlíková, Ph.D. / Dana.Stehlikova@phil.muni.cz

Department of Classical Studies

Masaryk University, Faculty of Arts

Arna Novaka 1, 60200 Brno, Czech Republic

4-6 gaudium...calefacit] cf. Galenus, De accidenti et morbo 5, 5

This work can be used in accordance with the Creative Commons BY-SA 4.0 International license terms and conditions (https://creativecommons.org/licenses/by-sa/4.0/legalcode). This does not apply to works or elements (such as image or photographs) that are used in the work under a contractual license or exception or limitation to relevant rights 
